\title{
Способ обнаружения шумовых сигналов источников радиочзлуения на основе фрактального анализа
}

\author{
P.P. Мухамедов 1, научный сотрудник, express2006@rambler.ru \\ B.В. Уткин ${ }^{1}$, к.т.н., доиент, научный сотрудник, ехрress2006@rambler.ru \\ Д.С. Войнов ${ }^{1}$, к.т.н., научный сотрудник, express2006@rambler.ru \\ ${ }_{1}$ Военный университет радиоэлектроники, г. Череповеи, 162622, Россия
}

Существующие энергетические обнаружители способны уловить сигнал при отношении сигнал/ шум не менее 20 дБ. Для энергетических обнаружителей утверждение о наличии сигнала делается по его мощности. LPI (Low-Probability-of-Intercept) - режим, подразумевающий использование сигналов с низким уровнем мощности. Уменьшение излучаемой пиковой мощности приводит к снижению дальности ведения радиотехнического наблюдения.

Для станций радиотехнического наблюдения необходима дальность обнаружения свыше 174 км, что не могут обеспечить энергетические обнаружители для радиолокационных станций, использующих данные виды сигналов. Следовательно, необходимо разработать обнаружитель, основанный не на мощности сигнала, а на иных физических принципах. Для решения данной задачи авторы рассматривают возможность применения фрактального анализа спектрограмм сигнала.

В статье представлены результаты фрактального анализа спектрограмм сигнала, позволяющего обнаруживать широкополосные сигналы с низким уровнем мощности.

Рассматриваемый вариант обнаружителя широкополосных сигналов на основе фрактального анализа спектрограмм позволяет обнаруживать сигналы при отношении сигнал/шум менее -5 дБ. Результаты были получены на основе моделирования широкополосных сигналов в среде РуCharm на языке программирования Руthon 3.8 с низким уровнем мощности и расчета фрактальных размерностей спектрограмм данных видов сигналов. По критерию согласия Пирсона доказано, что фрактальная размерность подчиняется нормальному закону распределения, следовательно, имеется возможность использования критерия обнаружения Неймана-Пирсона. На его основе рассчитаны вероятности правильного обнаружения данных видов сигналов, позволяющие сделать вывод, что при отношении сигнал/шум менее -5 дБ обеспечивается вероятность правильного обнаружения более 95 \%. Решение о наличии сигнала делается на основе расчета фрактальной размерности спектрограммы принятого сигнала.

Практическая значимость данной работы заключается в том, что фрактальный анализ обнаруженных сигналов позволяет выявить сигнал на большем расстоянии, чем при использовании энергетического способа обнаружения.

Ключевые слова: энергический обнаружитель, фрактальный анализ, фрактальная размерность, скрытность, отношение сигнал/шум, гауссов бельй шум.

Обнаружение радиосигналов на фоне помех является одной из важнейших задач радиотехники. Реальные радиотехнические системы радиолокации, радионавигации и связи всегда функционируют в условиях априорной неопределенности относительно вероятностей появления обнаруживаемых сигналов, а также параметрической, непараметрической и параметрико-непараметрической априорной неопределенности относительно статистических характеристик сигналов и помех. Это накладывает определенные требования на структуру функциональных операций, выполняемых при обнаружении, когда форма обнаруживаемого радиосигнала априори неизвестна и оптимальный приемник нереализуем. В работе [1] было предложено использовать в качестве обнару- жителя энергетический приемник, представляющий собой каскадно соединенные линейный полосовой фильтр (ЛПФ), квадратор, интегратор на интервале времени наблюдения и пороговое устройство (ПУ).

Ввиду универсальности энергический обнаружитель применяется в случае приема как детерминированных, так и стохастических радиосигналов. Однако недостатком данного обнаружителя является зависимость порога обнаружения от неизвестной в общем случае спектральной плотности мощности шума, что не гарантирует постоянного уровня ложных тревог при изменяющейся интенсивности помex.

Прогресс в развитии радиолокации, радионавигации и связи как в коммерческой, так и 


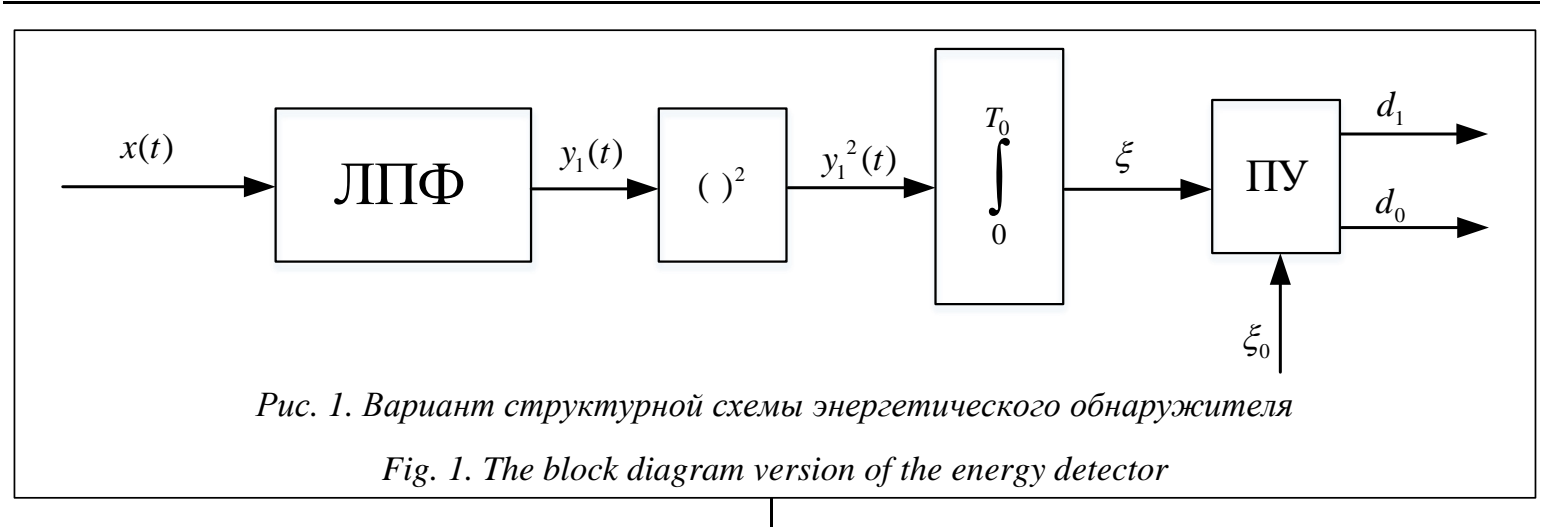

в военной отрасли предопределяет переход к сигналам с повышенной энергетической и структурной скрытностью. Повышенная скрытность достигается за счет применения многочастотных сигналов со сниженной излучаемой мощностью. Все это, а также существенные недостатки энергетического обнаружителя обусловили необходимость использования других способов обнаружения сигналов.

Для автоматического обнаружения сигналов радиотехническими системами предлагается использовать способ обнаружения сигналов источников радиоизлучений на основе фрактального анализа спектрограмм [2].

В настоящее время в средствах радиотехнического контроля используются энергетические обнаружители [3], вариант структурной схемы которых представлен на рисунке 1.

Данная схема включает в себя четыре каскада: ЛПФ, квадратичный детектор огибающей, интегратор и ПУ. Решение о наличии или отсутствии сигнала принимается по статистике на выходе обнаружителя, которая сравнивается со статистикой шума.

На рисунке 2 представлена рабочая характеристика данного обнаружителя при обнаружении импульса с линейной частотной модуляцуией (ЛЧМ) (длительность импульса $\tau_{\text {и }}=4$ мкс, ширина спектра $\Delta f=25$ МГц при условной вероятности ложной тревоги $F=10^{-5}$ и $F=10^{-9}$ ).

Из анализа графика, представленного на рисунке 2 , видно, что требуемая вероятность правильного обнаружения $P_{\text {по }}=0,95$ достигается при отношении сигнал/шум > 16 дБ. Следовательно, недостатком данного способа обнаружения является низкая вероятность правильного обнаружения сигналов при меньшем отношении сигнал/шум.

Предлагаемый способ обнаружения сигналов на основе фрактального анализа спектрограмм позволяет обнаруживать сигнал при меньшем отношении сигнал/шум $[4,5]$. Ранее он не применялся.
Данный способ может быть использован в средствах радиотехнического контроля для автоматического обнаружения сигналов. Цель его применения - расширение функциональных возможностей средств радиотехнического контроля в части, касающейся уменьшения значения отношения сигнал/шум, при котором обеспечивается требуемая вероятность правильного обнаружения сигналов $-P_{\text {по }} \geq 0,95$.

Достигаемым техническим результатом является повышение вероятности правильного обнаружения сигналов при низком отношении сигнал/шум (от -8 дБ и выше).

Блок-схема алгоритма, реализующего способ обнаружения сигналов источников радиоизлучения на основе фрактального анализа спектрограмм, представлена на рисунке 3 .

Оценка фрактальных свойств широкополосных сигналов представлена в окне программы (см. http://www.swsys.ru/uploaded/image/20211/2021-1-dop/9.jpg).

Процедуры, отображенные на схеме, реализуются поэтапно.

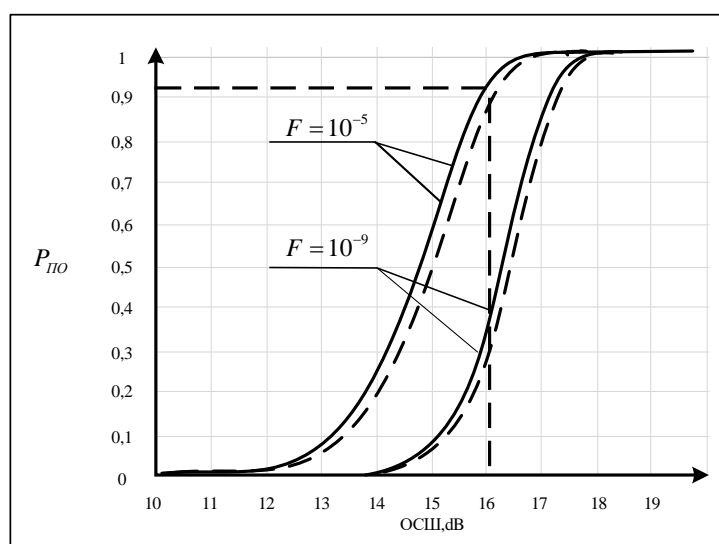

Рис. 2. Кривые обнаружения

при энергетическом обнаружении импульса c ЛЧМ

Fig. 2. Detection curves for energy detection of a pulse with an LFM 


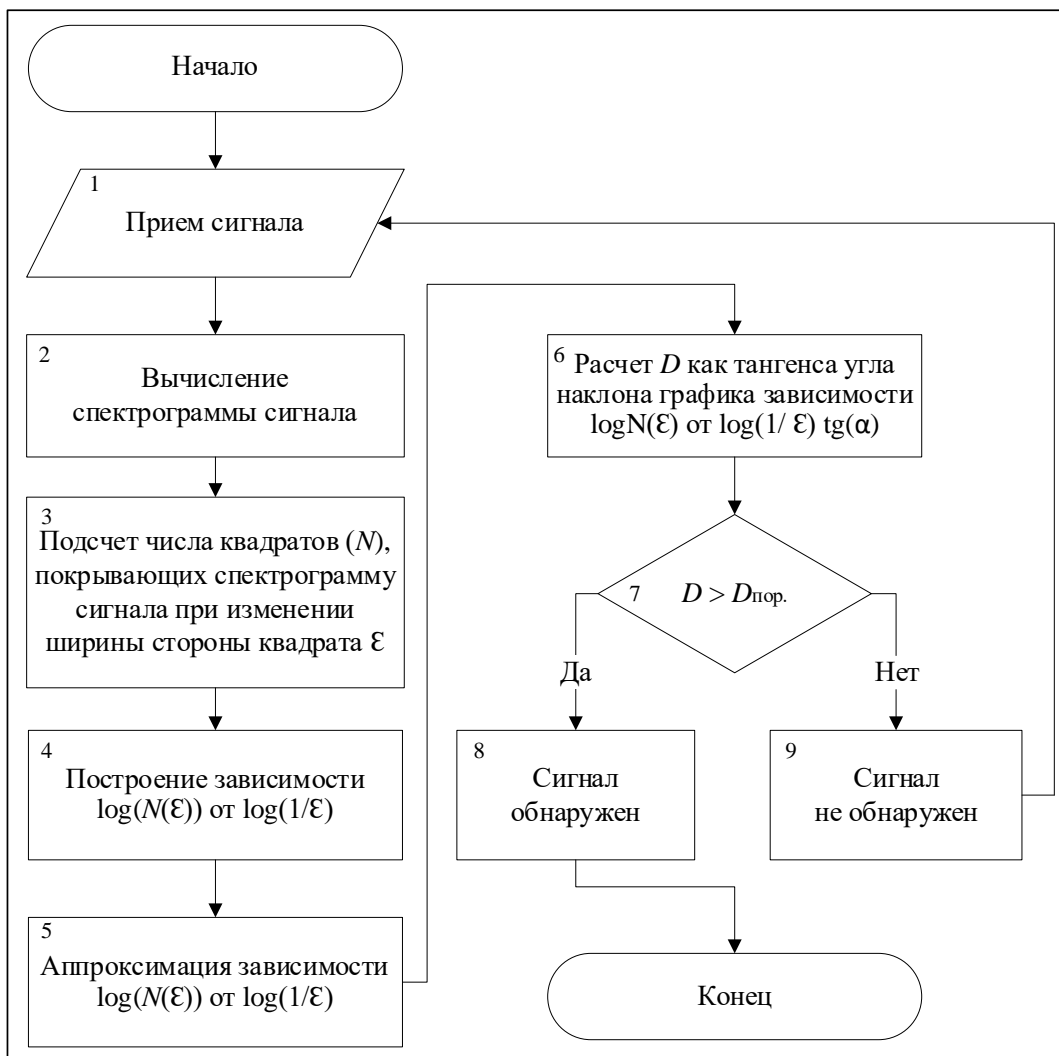

Рис. 3. Блок-схема алгоритма, реализующего способ обнаружения сигналов источников радиоизлучения на основе фрактального анализа спектрограмм

Fig. 3. Block diagram of an algorithm that implements a method for detecting radio sources based on fractal analysis of spectrograms

1. Вычисляется спектрограмма сигнала (рис. 4).

2. Задается ширина стороны квадрата $-\varepsilon$. Временная область существования исходных данных делится на квадраты длиной $\varepsilon$, рас- считывается число квадратов, накрывших все точки исследуемого множества (рис. 5). Полученное число квадратов обозначается $N(\varepsilon)$.

3. При изменении длин $\varepsilon$ изменяется число квадратов $N(\varepsilon)$. При малых $\varepsilon$ число элементов покрытия будет вести себя как $\varepsilon^{-D}$, где $D$ - искомая фрактальная размерность (рис. 6).

4. Вычисляется $\log N(\varepsilon)=$ $=-D^{*} \log (\varepsilon)$. На основе полученных данных строится зависимость $N(\varepsilon)$ от $\log (1 / \varepsilon)$. Чтобы оценить фрактальную размерность, необходим более линейный участок зависимости $N(\varepsilon)$ от $\log (1 / \varepsilon)$, на котором строится линейная аппроксимация вида $\log (N(\varepsilon))=-b^{*} \log (\varepsilon)+C$. Величина $D=-b$ является оценкой фрактальной размерности и представляет собой тангенс угла наклона $\operatorname{tg}(\alpha)$ данной прямой (рис. 7).

5. Делается вывод о наличии или отсутствии сигнала на основании сравнения полученной фрактальной размерности сигнала с фрактальной размерностью шума [6].

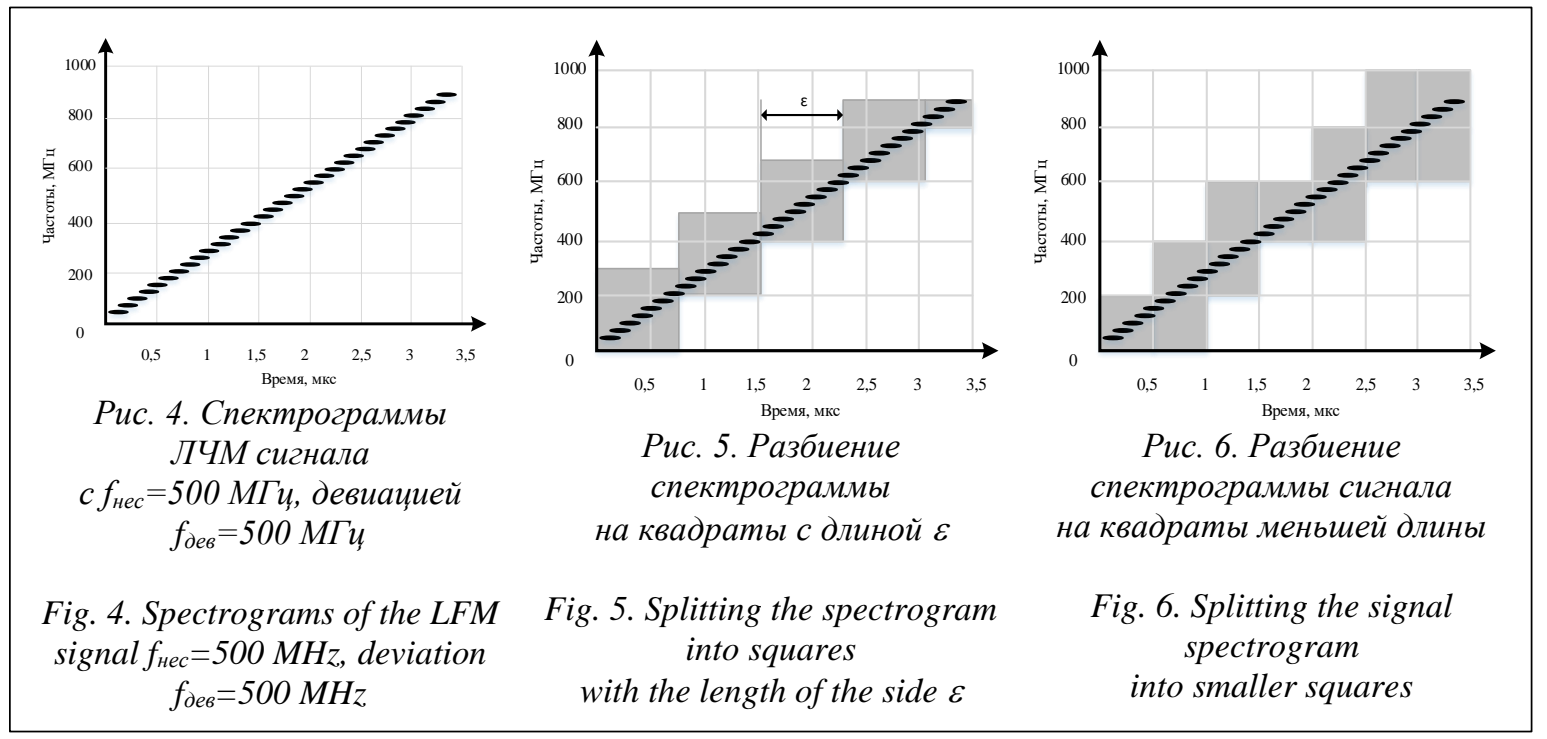




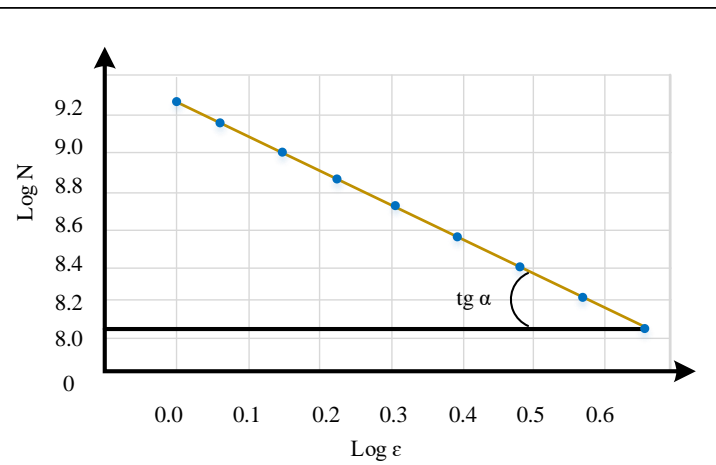

Рис. 7. Прямая расчета фрактальной размерности

Fig. 7. Direct calculation of fractal dimension

Способ обнаружения сигналов источника радиоизлучения на основе фрактального анализа спектрограмм [7] реализован в виде программы для ЭВМ, структурная схема которой представлена на рисунке 8 .

Для анализа эффективности разработанного способа был смоделирован гауссов белый шум (рис. 9a).

Смоделированы широкополосные сигналы с базой $B=100$ ЛЧМ с несущей частотой

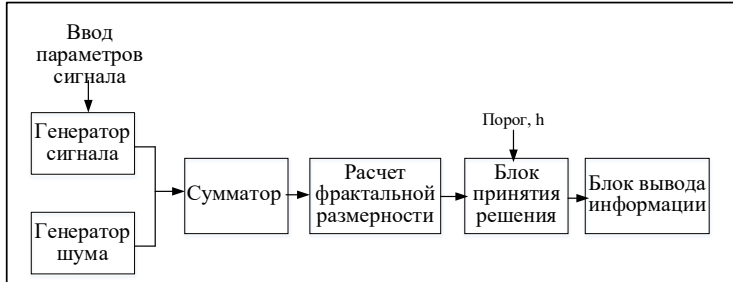

Рис. 8. Структурная схема программы

Fig. 8. The program structure

$f_{\text {нес }}=50 \mathrm{MГц,} \mathrm{девиацией} f_{\text {дев }}=25 \mathrm{MГц} \mathrm{(рис.} \mathrm{9б);}$ ФМ сигнал с различными кодами Баркера и несущей частотой $f_{\text {нес }}=150 \mathrm{MГц} \mathrm{(рис.} \mathrm{9в);} \mathrm{много-}$ частотный сигнал, состоящий из трех ЛЧМ импульсов с $f_{\text {нес }}=150$ МГц, $f_{\text {нес }}=750$ МГц, $f_{\text {нес }}=450$ МГц и $f_{\text {дев }}=25$ МГц, длительностью $\tau_{\text {и }}=4$ мкс и периодом следования $T_{\text {и }}=6$ мкс (рис. 9г).

Для гауссова белого шума и широкополосных сигналов рассчитаны фрактальные размерности при различном отношении сигнал/шум, графики зависимости значения фрактальной размерности от отношении сигнал/шум для шума и различных сигналов представлены на рисунке (см. http://www.swsys.ru/uploaded/image/2021-1/2021-1-dop/1.jpg).

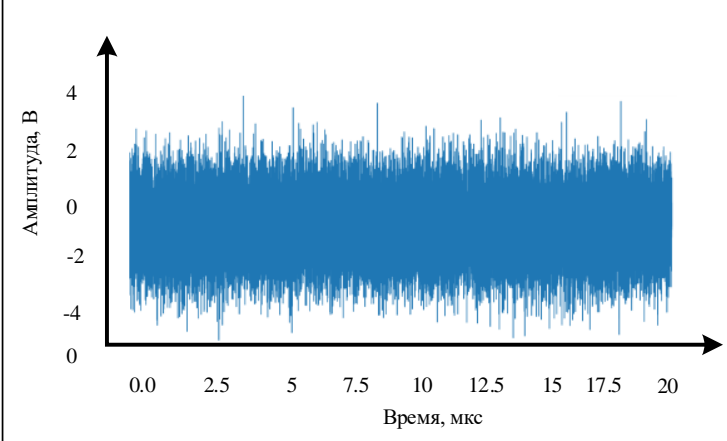

a)

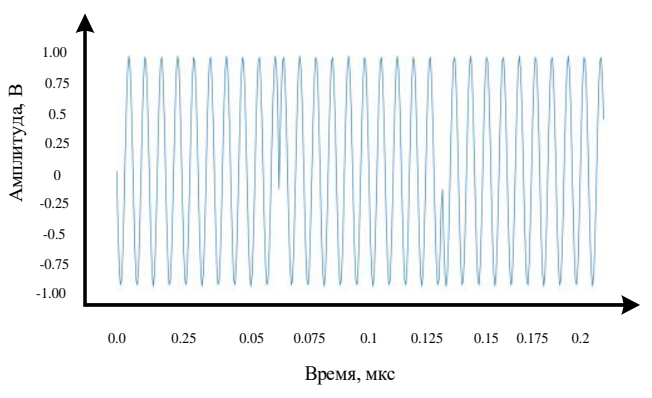

b)

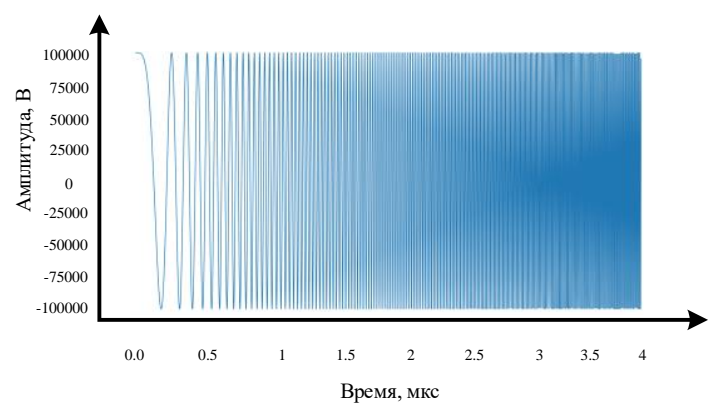

б)

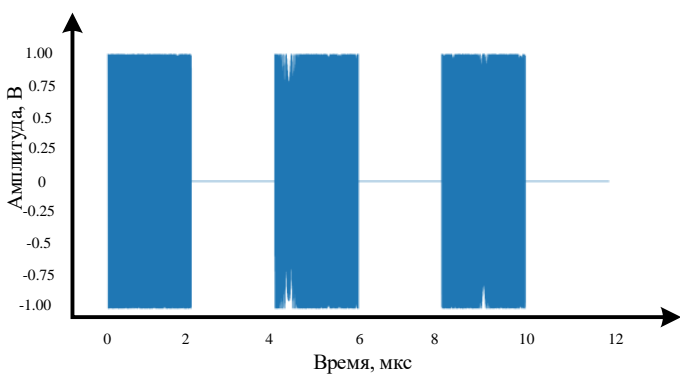

2)

Рис. 9. Временное представление сигнала: а) гауссов белый шум, б) ЛЧМ, в) ФМ, г) многочастотный сигнал

Fig. 9. Time representation signal: a) of Gaussian white noise, б) LFM, в) of the FM signal, 2) multi-frequency signal 
На основе анализа фрактальных размерностей сигналов [8] и шума была вычислена вероятность правильного обнаружения данных видов сигналов при использовании критерия обнаружения Неймана-Пирсона [9] (см. http:// www.swsys.ru/uploaded/image/2021-1/2021-1dop/2.jpg).

Анализ построенных графиков позволяет сделать вывод о том, что требуемая вероятность правильного обнаружения $P_{\text {по }}=0,95$ [10] достигается при минимальных значениях отношения сигнал/шум в пределах от -8 до -5 дБ для раз- личных видов сигналов. В сравнении с характеристиками для энергетического обнаружителя (минимальное значение отношения сигнал/шум $=16$ дБ для $\left.P_{\text {по }}=0,95\right)$ очевидно значительное повышение помехоустойчивости.

Таким образом, проведенные в данной области исследования расширяют возможности обработки сигналов с повышенной энергетической и структурной скрытностью. Полученные результаты подтверждают актуальность исследования в направлении фрактального анализа сигналов.

\section{Лumepamypa}

1. Urkowitz H. Energy detection of unknown deterministic signals. Proc. IEEE, 1967, vol. 55, no. 4, pp. 523-531.

2. Potapov A.A. Chaos theory, fractals and scaling in the radar: A look from 2015. In: The Foundations of Chaos Revisited: From Poincaré to Recent Advancements, 2016, pp. 195-218. DOI: 10.1007/978-3-31929701-9_12.

3. Костылев В.И., Гресь И.П. Улучшенный энергетический обнаружитель случайных гауссовых сигналов в коррелированном гауссовом шуме // XIX Междунар. науч.-технич. конф.: Радиолокация, навигация, связь. 2013. Т. 3. С. 2114-2124.

4. Potapov A.A. On the indicatrixes of waves scattering from the random fractal anisotropic surface. In: Fractal Analysis - Applications in Physics, Engineering and Technology, 2017, pp. 187-248. DOI: 10.5772/ intechopen.68187.

5. Потапов А.А. Фрактальные методы исследования флуктуаций сигналов и динамических систем в пространстве дробной размерности. В кн.: Флуктуации и шумы в сложных системах живой и неживой природы, 2008. С. 257-310.

6. Лазаренко О.В., Потапов А.А., Черногор Л.Ф. Фрактальные сверхширокополосные сигналы. В кн.: Информационная безопасность: метод шифрования. 2011. С. 151-187.

7. Потапов А.А., Матвеев Е.Н. Фрактальная электродинамика, скейлинг фрактальных антенн на основе кольцевых структур и мультимасштабные частотно-избирательные 3D-среды или фрактальные «сэндвичи»: переход к фрактальным наноструктурам // Радиотехника и электроника. 2010. Т. 55. № 10. C. $1157-1177$.

8. Потапов А.А. Многократное рассеяние волн на фрактальном ансамбле частиц и в больших неупорядоченных фрактальных системах // Сб. тезисов междунар. конф. Турбулентность, динамика атмосферы и климата. 2018. С. 564-573.

9. Храменков А.С., Ярмолик С.Н. Сопоставительный анализ радиолокационных обнаружителей, основанных на критерии Неймана-Пирсона и последовательном критерии отношения вероятностей // Докл. БГУИР. 2013. № 6. С. 72-78.

10. Костылев В.И., Гресь И.П. Статистический анализ эффективности обнаружения случайных сигналов на фоне полигауссовского шума с помощью обобщенного энергетического обнаружителя первого порядка // Вестн. ВГУ: Системный анализ и информационные технологии. 2015. № 3. С. 75-83.

\section{Method for detecting source noise signals of the radio emission based on fractal analysis}

R.R. Mukhamedov ${ }^{1}$, Research Associate, express2006@ rambler.ru

V.V.Utkin ${ }^{1}$, Ph.D. (Engineering), Research Associate, express2006@rambler.ru

D.S. Voinov ${ }^{1}$, Ph.D. (Engineering), Research Associate, express2006@ rambler.ru

${ }^{1}$ Military University of Radioelectronics, Cherepovets, 162622, Russian Federation

Abstract. Existing energy detectors can detect a signal at a SNR of at least $20 \mathrm{~dB}$. For energy detectors, the statement about the presence of a signal is made by the signal strength. LPI (low-probability-of-inter- 
cept) - mode, implies the use of signals with a low power level. A decrease in the radiated peak power leads to a decrease in the range of conducting radio surveillance.

For radio surveillance stations, it is necessary to provide a detection range of over $174 \mathrm{~km}$, which is not provided by energy detectors for radar stations using these types of signals, therefore, it is necessary to develop a detector based not on the signal power, but on other physical principles. To solve this problem, the authors consider the possibility of using fractal analysis of signal spectrograms.

To present the results of the fractal analysis of the signal spectrograms, which allows detecting broadband signals with a low power level.

The considered version of the broadband signal detector, based on the fractal analysis of spectrograms, allows detecting signals with a signal-to-noise ratio of less than $-5 \mathrm{~dB}$. The results were obtained based on modeling broadband signals in the PyCharm environment in the Python 3.8 programming language, with a low power level, and calculating the fractal dimensions of the spectrograms of these types of signals. According to the Pearson agreement criterion, it is proved that the fractal dimension obeys the normal distribution law, therefore, it is possible to use the Neumann - Pearson detection criterion. The probabilities of correct detection of these types of signals are calculated based on the criterion. Based on these calculations, it was concluded that with a signal-to-noise ratio of less than $-5 \mathrm{~dB}$, the probability of correct detection is over $95 \%$. The decision about the presence of a signal is made based on the calculation of the fractal dimension of the spectrogram of the received signal.

The practical significance of this work lies in the fact that the use of fractal analysis of detected signals makes it possible to detect a signal at a greater distance than when using the energy detection method.

Keywords: energy detector, fractal analysis, fractal dimension, stealth, signal-to-noise ratio, Gaussian white noise.

\section{References}

1. Urkowitz H. Energy detection of unknown deterministic signals. Proc. IEEE, 1967, vol. 55, no. 4, pp. 523-531.

2. Potapov A.A. Chaos theory, fractals and scaling in the radar: A look from 2015. In: The Foundations of Chaos Revisited: From Poincaré to Recent Advancements, 2016, pp. 195-218. DOI: 10.1007/978-3-319-29701-9_12.

3. Kostylev V.I., Gres I.P. Improved energy detector of random Gaussian signals in correlated Gaussian noise. Proc. XIX Intern. Sci. and Tech. Conf.: Radiolocation, Navigation, Communication, 2013, vol. 3, pp. 2114-2124 (in Russ).

4. Potapov A.A. On the indicatrixes of waves scattering from the random fractal anisotropic surface. In: Fractal Analysis - Applications in Physics, Engineering and Technology, 2017, pp. 187-248. DOI: 10.5772/intechopen.68187.

5. Potapov A.A. Fractal methods for studying fluctuations of signals and dynamical systems in the space of fractional dimension. In: Fluctuations and Noises in Complex Systems of Living and Inanimate Nature, 2008, pp. 257-310 (in Russ.).

6. Lazarenko O.V., Potapov A.A., Chernogor L.F. Fractal ultra-wideband signals. In: Information Security: Encryption Method, 2011, pp. 151-187 (in Russ.).

7. Potapov A.A., Matveev E.N. Fractal electrodynamics, scaling of fractal antennas based on ring structures and multi-scale frequency-selective 3D media or fractal "sandwiches": transition to fractal nanostructures. Journal of Communications Technology and Electronics, 2010, vol. 55, no. 10, pp. 1157-1177 (in Russ.).

8. Potapov A.A. Multiple scattering of waves on a fractal ensemble of particles and in large disordered fractal systems. Proc. Intern. Conf. Turbulence, Dynamics of the Atmosphere and Climate, 2018, pp. 564-573 (in Russ.).

9. Khramenkov A.S., Yarmolik S.N. The comparative analysis of radar-tracking searchers based on Neiman-Pierson criterion and sequential probability ratio test. Dokl. BGUIR, 2013, no. 6, pp. $72-78$ (in Russ.)

10. Kostylev V.I., Gres I.P. The statistical analysis of efficiency of detection of random signals against Polygaussian noise by means of the generalized energy detector of the first order. Proc. of Voronezh State University. Ser.: Systems Analysis and Information Technologies, 2015, no. 3, pp. 75-83 (in Russ.).

\section{Для цитирования}

Мухамедов Р.Р., Уткин В.В., Войнов Д.С. Способ обнаружения шумовых сигналов источников радиоизлучения на основе фрактального анализа // Программные продукты и системы. 2021. T. 34. № 1. C. 195-200. DOI: 10.15827/0236-235X.133.195-200.

\section{For citation}

Mukhamedov R.R., Utkin V.V., Voinov D.S. Method for detecting source noise signals of the radio emission based on fractal analysis. Software \& Systems, 2021, vol. 34, no. 1, pp. 195-200 (in Russ.). DOI: 10.15827/0236-235X.133.195-200. 